\title{
The Implementation of Criminal Sanctions on Criminal Acts of Narcotics
}

\author{
Mei Ristikowati ${ }^{*}$ and Lathifah Hanim**) \\ ${ }^{*}$ Advocate, E-mail: meiharyono440@gmail.com \\ **) Faculty of Law Universitas Islam Sultan Agung
}

\begin{abstract}
.
This study aims to examine and analyze the application of criminal sanctions against perpetrators of narcotics crimes and judges' considerations in the application of sanctions to perpetrators of narcotics crimes in the Batang District Court. The research method used is a Sociological Juridical Approach. Based on the results of the research on the application of criminal sanctions against perpetrators of narcotics crimes, starting from the indictment of the public prosecutor, who charged him with the Subsidarity charge, namely Article 114 paragraph (1), Article 112 (1) and Article 127 of Act No. 35 of 2009 concerning Narcotics. The basis for the examination in court is the Indictment of the Public Prosecutor, then the Panel of Judges conducts an examination of the indictment, in order to prove whether the Defendant has committed the crime as stated in the Article charged by the public prosecutor, whether the description of the defendant's actions is correct, which will be proven based on the applicable legislation. Considering the panel of judges in their decision, the panel of judges in their examination uses the theory of proof and punishment, where in the Aquo case the panel of judges will prove the elements contained in Article 114 paragraph (1), Article 112 (1) and Article 127 of Act No. 35 of 2009 concerning Narcotics as stated in the indictment of the public prosecutor, then examine the statements of witnesses, associated with the statements of the defendant and documentary evidence so that the facts of the trial will be obtained and evidence will be obtained which are mutually compatible and mutually reinforcing, from the results the research according to the authors of the panel of judges in court examinations has been based on the theory of evidence and the theory of punishment. Keywords: Criminal; Decision; Judge; Narcotic; Sanction.
\end{abstract}

\section{Introduction}

The crime of Narcotics and Psychotropics as referred to in Act No. 5 of 1997 concerning Psychotropics, and Act No. 22 of 1997 concerning Narcotics provides fairly heavy criminal sanctions, however, in reality the perpetrators of crimes are actually increasing. ${ }^{1}$ In Act No. 35 of 2009 has the spirit to save narcotics abusers, that this Law aims to prevent, protect, and save the people of Indonesia. ${ }^{2}$

Cases of abuse and illicit trafficking of Narcotics are one of the cases that are often processed to the court by law enforcers, data sourced from the Directory of Decisions of the Batang District Court, shows that from 2012 to 2021 there were

\footnotetext{
${ }^{1}$ Sri Endah Wahyuningsih, "Penegakan Hukum Pidana Terhadap Pengguna Narkoba di Polda Jateng", Jurnal Daulat Hukum. Vol. 12. No. 3 September 2017.

${ }^{2}$ Carto Nuryanto, "Rekontruksi Saksi Pidana dan Rehabilitasi Pemberantasan Korban Narkoba Berdasarkan Keadilan Agama", Jurnal Daulat Hukum Vol. Issue 1 June 2019, see to Chuasanga A., Ong Argo Victoria, 2019, "Legal Principles Under Criminal Law in Indonesia and Thailand", Jurnal Daulat Hukum, Vol 2, No 1 (2019) http://jurnal.unissula.ac.id/index.php/RH/article/view/4218
} 
307 cases that had been decided in court. ${ }^{3}$ This data is also reinforced by the report directory of the Semarang High Court's decisions from 2011 to 2021 which continues to show an increase, with a total of 1550 narcotics and psychotropic cases being decided, and increasing every year. ${ }^{4}$ Sociologically, the impact of the illicit trafficking of narcotics is to capture as many narcotics abusers as possible. ${ }^{5}$

According to Sudarto, the functions of criminal law are divided into 2 (two) namely general functions and special functions. The general function of criminal law is the same as the function of law in general, namely regulating social life or organizing order in society and the special function of criminal law is protecting legal interests against acts that want to rape them with criminal sanctions. ${ }^{6}$ The judge in court examines carefully and then in the end determines the appropriate form of punishment for the perpetrators of the crime. Another thing that the judge needs to pay attention to in making a decision is the use of the theory of punishment. The use of this theory of punishment is important because the criminal sanctions imposed by the judges, including the severity of the sanctions, which are the basis of the theory of justice used by the judges, are considered odd if the decision is not based on on the theory of punishment developed in Indonesia. ${ }^{7}$ Another thing that the judge needs to pay attention to in deciding the decision is the use of the theory of punishment, regarding the theory of punishment in general, it is grouped into three groups, namely, absolute theory, theory of retaliation and relative theory. ${ }^{8}$ Several Narcotics cases that have been decided include the Narcotics case that ensnared Fitri Andriana bint Mukhlasin, which has been decided by the Panel of Judges. the public prosecutor, considering the many incidents in the field that show that in the prosecution process, the public prosecutor mostly often uses articles with much heavier provisions, namely in the primary indictment of violating Article 114 paragraph (1) of the Republic of Indonesia Act No. 35 of 2009 concerning Narcotics and the Subsidiary indictment of Article 112 Paragraph (1) of the Law of the Republic of Indonesia Number 35 of 2009 concerning Narcotics, whereas the criminal provisions for Narcotics abusers have been regulated in Article 127 of Act No. 35 of 2009 with a maximum imprisonment of 4 years, even if the Narcotics abuser is an addict, the judge can give criminal sanctions in the form of rehabilitation. ${ }^{9}$ Based on this sociological background, it is interesting for the author to examine the judge's considerations in determining criminal sanctions against narcotics crime perpetrators, while the research objectives in this paper are: How is the application of criminal sanctions against narcotics criminal acts in the Batang District Court?

\footnotetext{
${ }^{3}$ Batang District Court Decision Directory

${ }^{4}$ Directory of Central Java High Court Decisions

${ }^{5}$ Rikhi Benindo Maghaz, "Permasalahan Penuntutan Terhadap Pelaku Penyalah Guna Narkotika Di Wikayah Hukum Kejaksaan Negeri Padang”, Jurnal Cendekia Hukum, Vol.4,No 2, March 2019.

${ }^{6}$ Eddy. OS Hiariej, 2016, Prinsip-Prinsip Hukum Pidana. Yogyakarta: Cahaya Atma. p. 34.

${ }^{7}$ Sri Endah Wahyuningsih, Soesilo Atmoko, Muchamad Ikhsan, The Implementation Of Punishment Theories In The Verdict Of Narcotics Case By Judge In Indonesia, Test Engineering \& Management, Vol 83 Number 2797-2806, March-April 2020.

${ }^{8}$ E Utrecht, Hukum Pidana I, 1958, Jakarta: Universitas Jakarta, p. 157

${ }^{9}$ Decision Number 179/Pid.Sus/2019/PN.Btg
} 


\section{Research Methods}

This research is classified in descriptive analytical research where this research aims to explain, summarize various conditions, various situations or various variables that arise in the community which is the object of the research based on what happened and look for relationships between the variables studied. The method in this study uses a sociological juridical approach, the data needed are primary data, secondary data, and data collection methods are observation, interviews (interviews) and documentation. Data analysis in this study uses qualitative descriptive methods, research using qualitative methods departs from assumptions about reality or phenomena that are unique and complex.

\section{Results and Discussion}

A criminal act is an act of doing something that has an element of error as an act that is prohibited and is threatened with a crime, where the criminal imposition of the perpetrator is for the sake of maintaining legal order and ensuring the public interest. ${ }^{10}$ Criminal acts are also defined as human behavior that is formulated in the law, against the law, which deserves to be punished and committed with errors, a person who commits a criminal act will be held accountable for his actions with a criminal if he has an error, a person has an error if at the time of committing the act it is seen from the perspective of the law. From the perspective of society, it shows a normative view of the mistakes made. ${ }^{11}$

Criminal sanctions in English, called criminal sanctions while in Dutch, called strafrechtelijke sancties are punishments imposed on perpetrators who commit criminal acts which include, sanctions and criminal. ${ }^{12}$ At first glance, people will think that criminal matters are only a matter of judges, if viewed from Article 10 of the Criminal Code, then related to criminal decisions only concerning judges, but this is not entirely true, for example in prison sentences, judges only determine the limits while the procedure for sentencing details determined by the Correctional Institution. ${ }^{13}$ The judge at the trial court examines carefully and then determines the form of punishment that remains for the perpetrators of the crime. Decisions on narcotics abuse crimes are also a consequence of a criminal justice system, both in terms of law enforcement and legislation, from enforcement at the investigation stage to prosecution to the judge's decision. ${ }^{14}$

Based on this, this study describes the decision of case Number 247/Pid.Sus/2019/PN.Btg through the case study method. Sequentially the meanings are 1) an example of something happening, 2) the actual condition of a situation or situation and 3 ) a certain environment or condition about a person or

\footnotetext{
${ }^{10}$ P.A.F. Lamintang. Franciscus Theojunior Lamintang, 2019, Dasar-Dasar Hukum Pidana Di Indonesia, Jakarta: Sinar Grafika, p.192

${ }^{11}$ Andi Hamzah, 2001, Bunga Rampai Hukum Pidana dan Acara Pidana, Jakarta: Ghalia Indonesia, p. 22

${ }^{12}$ Rodliyah, H. Salim HS, 2017, Hukum Pidana Khusus. Depok: Rajawali Pers. p. 87-88

13 Muhammad, D, 1988, Sari Kuliyah Hukum Pidana dan Acara Pidana, Pelatihan calon.

${ }^{14}$ Defri Dwi Irmawan and Anis Mashdurohatun, "Disparitas Perkara Pidanaterhadap Putusan hakim Dalam Tindak Pidana Narkotika Penyalahgunaan dilihat Dari Tujuan Hukum Pidana”, Jurnal daulat Hukum Volume 1 Issue 4 December 2018
} 
thing. ${ }^{15}$ Based on the investigation and investigation of the Law Enforcement Officials, the following descriptions of legal events were obtained:

That started on Tuesday, October 08, 2019 at around 20:44 WIT, the Defendant sent a message to witness Indha Ashadi, S, H. Through the Whatsaap application by asking "Brother, is there any information on selling white or not, if there is any information, please let me know" (brother, is there any information on selling methamphetamine or no, if there is, let me know) and witness Indha Ashadi, S,H answered, "I'll ask you tomorrow." That furthermore on Wednesday 5th October 09, 2019 the Defendant again sent a message to witness Indha Ashadi, $\mathrm{SH}$, through the WhatsApp application by asking "mas priwe" (how are you?) which was then answered by witness Indra Ashadi, SH "600 put special items" (six hundred puts of special items) which was then answered by the Defendant "ok, gpp bang, when can it be, when can it be taken? I came home late at 10 o'clock and went straight to my brother's house "(okay, no problem, bro, when it can be taken? I come home overtime at 10 o'clock directly to my brother's house). Where then the Defendant at around 22.00 WIT left for the witness's house Indha Ashadi, SH, after the Defendant arrived at the house of witness Indha Ashadi, SH, which was in Jatisati Village Rt 04 Rw 01 Subah District, Batang Regency then the Defendant entered the house and gave money amounting to Rp 700,000,- (Seven hundred thousand Rupiah) to witness Indha Ashadi, SH, who then witness Indha Ashadi, SH, left a few minutes later witness Indha Ashadi, SH, came by giving 1 (one) package of methamphetamine in a plastic clip wrapped the red cigarette wrapping paper which was received by the Defendant, which the Defendant immediately put into his left shirt pocket.

That furthermore, on Thursday, October 10, 2019 at around 01.00 WIB the Defendant was in front of the K24 Pharmacy located in the village of Kauman, Batang District, Batang Regency, when the Defendant was about to buy a glass pipette, suddenly several members of the police arrested the Defendant who At that time a body search was carried out on the Defendant and found 1 (one) package of methamphetamine in a plastic clip wrapped in red cigarette wrapping paper which was inserted into a Malboro cigarette pack which at that time was found in the left pocket of the shirt used by the Defendant. At that time, the Defendant admitted that 1 (one) package of methamphetamine in a plastic clip wrapped in red cigarette wrapping paper which was inserted in a Malboro cigarette pack belonged to the Defendant.

That the Defendant carried out his actions without permission from the authorized party or official

Whereas the evidence found has been tested by the Central Police Forensic Laboratory Semarang Branch based on the Minutes of Criminalistic Laboratory Examination No. Lab : 2620/NNF/2019 dated October 23, 2019 signed by Drs Teguh Prihmono, MH, Ibnu Sutanto, ST, Eko Fery Prasetyo, S, Si, as examiner and known by Dr. Nursamran, M, Si as head of the Forensic Laboratory with the result

\footnotetext{
15 Mudjia Raharjo, 2017, Studi Kasus dalam penelitian Kualitatif: Konsep dan Prosedurnya. Malang:
} Universita Islam Negeri maulana Malik Ibrahim. p.3. 
is that the evidence number BB-5377/2019/NNF is in the form of 1 (one) plastic clip wrap containing crystal powder with a net weight of 0 powder. ${ }^{16}$

\section{a. Public Prosecutor's Indictment}

- Primary actions of the Defendant as regulated and subject to criminal sanctions in Article 114 Paragraph (1) of the Law of the Republic of Indonesia Number 35 of 2009 concerning Narcotics. Subsidiary actions of the Defendant as regulated and subject to criminal sanctions in Article 112 Paragraph (1) of the Law of the Republic of Indonesia Number 35 of 2009 concerning Narcotics.

- More subsidiary actions of the Defendant as regulated and subject to criminal sanctions in Article 127 Paragraph (1) of the Law of the Republic of Indonesia Number 35 of 2009 concerning Narcotics.

\section{b. The Prosecutor's Claim in a nutshell}

The Public Prosecutor charged the defendant as follows;

- Stating that the Defendant M. Adi Saputra Alias Putra Bin Asmadi above has been legally and convincingly proven guilty of committing a crime "unlawfully or against the law buying Narcotics Category I" as regulated and subject to criminal sanctions in Article 114 Paragraph (1) of the Republic of Indonesia Act No. 352009 concerning Narcotics as in the Primary indictment

- Sentenced the Defendant M. Adi Saputra Alias Putra bin Asmadi therefore with a 6 (six) year imprisonment reduced as long as the Defendant was in custody with an order that the Defendant be detained and a fine of Rp. 1,000,000,000 (one billion Rupiah) provided that if cannot be paid by the Defendant, it will be replaced with a sentence of 4 (four) months in prison;

\section{c. The verdict of the panel of judges in a nutshell}

The Panel of Judges in their decision handed down the sentence to the Defendant as follows:

- To declare that the Defendant, M. Adi Saputra, Alias Putra Bin Asmadi, has not been legally and convincingly proven guilty of committing a crime as stated in the Primary and Subsidiary charges;

- Release the Defendant M. Adi Saputra Alias Putra Bin Asmadi from the aforementioned Primary and Subsidiary Indictments;

- Declaring that the Defendant M. Adi Saputra Alias Putra bin Asmadi has been proven legally and convincingly guilty of committing the crime of "Narcotics Abusers Group I";

- Sentencing the Defendant therefore with imprisonment for 3 (three) years; ${ }^{17}$

The application of criminal sanctions in the Aquo case, the author of the analysis begins with a review of legislative policies (policy legislation) which contains the formulation of criminal provisions in the Law of the Republic of Indonesia Number 35 of 2009 concerning Narcotics. The analysis is on the Juridical Construction Article 114 paragraph (1), Article 112 Paragraph (1) and Article 127

\footnotetext{
16 Batang District Court Decision Number 247/Pid.Sus/2019/PN

17 Ibid
} 
of Act No. 35 of 2009,18 The explanation in these articles, based on the understanding of systematic construction, what the author means is criminal provisions containing a formulation stating criminal provisions for violations of provisions containing prohibition norms or orders. ${ }^{19}$ The substantive criminal system is essentially a criminal provision in the law under study which is part of the overall criminal system or criminal law system currently in force in the Narcotics Act No. right or against the law offering for sale, selling, buying, receiving, intermediary in buying and selling, exchanging or delivering Narcotics Category I, the juridical formulation as previously defined, the pattern of punishment or the formulation or formulation of a criminal in the article above explains, the existence of a legal subject, criminal acts, and criminal sanctions, as well as those contained in Article 112 paragraph (1) of Act No. 35 of 2009 concerning Narcotics, which explains the formulation of the action being convicted of showing an act in the form of unlawfully possessing, storing, controlling, or providing Narcotics Category I not a plant is an act committed by the perpetrator contrary to positive law or applicable laws and regulations and the act is carried out without there is a permit from the authorized official, then Article 127 of Act No. 35 of 2009 concerning Narcotics explains about Narcotics Users with the formulation of the element of anyone who uses Narcotics without rights or against the law, while what is meant by "without rights" is without permission and authority to do something deed. Meanwhile, what is meant by breaking the law is an act that is contrary to the law or contrary to the applicable laws and regulations. ${ }^{20}$

The results of the interview from the Judge of the Batang Guntoro District Court, Eka Sekti, SH. MH, (Chairman of the Batang District Court), that the basis of the examination at the Batang District Court is an indictment letter from the public prosecutor, then what is sought to prove whether the defendant in this case has committed a crime as stated in the public prosecutor's indictment, and whether the act was true or not. , will be carried out by a process of proof using evidence based on the applicable legislation, and in the trial process the panel of judges applies the principle of Audi et Alteram Partem which means listening to both parties, both from the public prosecutor and from the defendant, ${ }^{21}$ that a person's intention or intent is part of the teaching on wrongdoing which states that "there is no crime without guilt" as referred to in the formulation of norms and the accompanying criminal sanctions.

A person cannot be punished without being proven guilty which is the same as an error in the norm of criminal provisions, so punishing someone who has no intention of committing a crime is a very serious violation of the law. Based on the facts above, furthermore, it turns out that the public prosecutor in his proof, there is not a single piece of evidence that can show that the defendant's guilt as contained in the elements of Article 114 paragraph (1) of Act No. 35 of 2009

\footnotetext{
18 Act No. 35 of 2009 concerning Narcotics

19 Barda Nawawi Arief, 2012, Kebijakan Formulasi Ketentuan Pidana Dalam Peraturan PerundangUndangan. Semarang: Pustaka Magister, p.12.

${ }^{20}$ Eddy Q. Op.cit, p. 232.

${ }^{21}$ Guntoro Eka Sekti, Chairman of the Batang District Court, Personal interview, Batang, Thursday 25 November 2021.
} 
concerning Narcotics, Whereas later in the aquo case, the panel of judges in Article 127 of Act No. 35 of 2009 concerning Narcotics considered that the element of each abuser referred to as "abuser" is a person who uses narcotics without rights or against the law while what is meant by "without rights" is without permission and authority commits an act, while what is meant by "against the law" is an act that is contrary to the applicable laws and regulations.

Based on the facts revealed at the trial, as the panel of judges considered that as has been considered in the previous element contained in the chronology in the Aquo case above, namely on Wednesday, October 9, 2019 the Defendant ordered methamphetamine from witness Indha Ashadi, SH. Where then the Defendant at around 22.00 WIB went to the house of witness Indha Ashadi, then witness Indha Ashadi, SH. came by giving 1 (one) package of methamphetamine in a plastic clip wrapped in red cigarette wrapping paper which was received by the Defendant who immediately put the Defendant into his left shirt pocket, thus the Defendant's actions were contrary to and violated the regulated laws and regulations. explicitly stated, then the element of "Narcotics Group I For Yourself" has been fulfilled, that based on the results of the panel of judges' research in the application of criminal sanctions against narcotics criminals, the theory of punishment and the theory of evidence have been used.

Consideration of the panel of judges in deciding the Aquo case, there were found several facts and legal opinions of the panel of judges as follows, Proof of Legality Principle, Proof of Cultivation Principle (Error of the criminal act), Proof of Criminal Liability. One of the judges' considerations in imposing a sentence is the things that relieve the defendant and assess the circumstances contained in the defendant. ${ }^{22}$ However, in Article 127 paragraph (2) of Act No. 35 of 2009 it is stated that the judge states that the judge must consider, pay attention to the provisions of Article 54, Article 55, and Article 103 in the decision, ${ }^{23}$ but in the Aqou case the implementation depends on the investigator and the public prosecutor, if the public prosecutor does not refer to the provisions of Article 127 paragraph (2) of Act No. 35 of 2009 concerning charges, then placing drug users in rehabilitation institutions is difficult.

\section{Conclusion}

The application of criminal witnesses against perpetrators of narcotics crimes, starting with the indictment of the public prosecutor, who charged him with the indictment of Subsidarity, namely Article 114 paragraph (1), Article 112 (1) and Article 127 of Act No. 35 of 2009 concerning Narcotics. The basis for the examination in court is the Indictment of the Public Prosecutor, then the Panel of Judges conducts an examination of the indictment, in order to prove whether the Defendant has committed such a crime. The panel of judges will provide equal opportunities for both the public prosecutor and the defendant in submitting

\footnotetext{
${ }^{22}$ Eka Santosa, "Putusan Tindak Pidana Narkoba Dalam Hukum Islam Perspektif Dan Perlindungan Hak Asasi Manusia", Jurnal Daulat Hukum Vol. 1 Issue 2 December 2019.

${ }^{23}$ Bambang Rudi Hartoko, Umar Ma'ruf, "Kontroversi Sanksi Pidana Terhadap Penyalahguna Narkotika Dalam Undang-Undang Nomor 35 Tahun 2009", Jurnal Daulat Hukum Volume 1 Issue, 4 December 2019.
} 
evidence, and the panel of judges will judge from the evidence submitted, what actions are proven and not proven, then the panel of judges will determine the appropriate criminal sanctions or in accordance with the facts and evidence obtained during the trial process.

\section{References}

\section{Journals:}

[1] Bambang Rudi Hartoko and Umar Ma'ruf, "Kontroversi Sanksi Pidana Terhadap Penyalahguna Narkotika Dalam Undang-Undang Nomor 35 Tahun 2009", Jurnal Daulat Hukum Volume 1 Issue, 4 December 2019.

[2] Carto Nuryanto. "Rekontruksi Saksi Pidana dan Rehabilitasi Pemberantasan Korban Narkoba Berdasarkan Keadilan Agama", Jurnal Daulat Hukum Unissula. Vol. Issue 1 June 2019.

[3] Chuasanga A., Ong Argo Victoria. "Legal Principles Under Criminal Law in Indonesia and Thailand", Jurnal Daulat Hukum, Vol 2, No 1 (2019) http://jurnal.unissula.ac.id/index.php/RH/article/view/4218

[4] Defri Dwi Irmawan and Anis Mashdurohatun, "Disparitas Perkara Pidana terhadap Putusan hakim Dalam Tindak Pidana Narkotika Penyalahgunaan dilihat Dari Tujuan Hukum Pidana", Jurnal Daulat Hukum Volume 1 Issue 4 December 2018

[5] Eka Santosa, "Putusan Tindak Pidana Narkoba Dalam Hukum Islam Perspektif Dan Perlindungan Hak Asasi Manusia”, Jurnal Daulat Hukum Vol. 1 Issue 2 December 2019.

[6] Rikhi Benindo Maghaz, "Permasalahan Penuntutan Terhadap Pelaku Penyalah Guna Narkotika Di Wikayah Hukum Kejaksaan Negeri Padang", Jurnal Cendekia Hukum. Vol.4,No 2, March 2019.

[7] Sri Endah Wahyuningsih, Soesilo Atmoko, Muchamad Ikhsan, "The Implementation Of Punishment Theories In The Verdict Of Narcotics Case By Judge In Indonesia", Test Engineering \& Management, Vol 83 Number 27972806, March-April 2020.

[8] Sri Endah Wahyuningsih, Penegakan Hukum Pidana Terhadap Pengguna Narkoba di Polda Jateng", Jurnal Daulat Hukum. Vol. 12. No. 3 September 2017.

\section{Books:}

[1] Andi Hamzah, 2001, Bunga Rampai Hukum Pidana dan Acara Pidana, Jakarta: Ghalia Indonesia.

[2] Barda Nawawi Arief, 2012, Kebijakan Formulasi Ketentuan Pidana Dalam Peraturan Perundang-Undangan. Semarang: Pustaka Magister.

[3] E Utrecht, Hukum Pidana I, 1958, Jakarta: Universitas Jakarta.

[4] Eddy. OS Hiariej, 2016, Prinsip-Prinsip Hukum Pidana. Yogyakarta: Cahaya Atma.

[5] Mudjia Raharjo, 2017, Studi Kasus dalam penelitian Kualitatif: Konsep dan Prosedurnya. Malang: Universita Islam Negeri maulana Malik Ibrahim.

[6] Muhammad, D, 1988, Sari Kuliyah Hukum Pidana dan Acara Pidana, Pelatihan calon. 
[7] P.A.F. Lamintang. Franciscus Theojunior Lamintang, 2019, Dasar-Dasar Hukum Pidana Di Indonesia, Jakarta: Sinar Grafika.

[8] Rodliyah, H. Salim HS, 2017, Hukum Pidana Khusus. Depok: Rajawali Pers.

[9] Soerjono, Soekanto dan Sri Mamudji, 1985, Penelitian Hukum Normatif Suatu Tinjauan Singkat. Jakarta: CV.Rajawali

[10] Soerjono, Soekanto, 1985, Pengantar Penelitian Hukum. Jakarta: UI-Press.

\section{Regulation:}

[1] Act No. 35 of 2009 concerning Narcotics

[2] Batang District Court Decision Directory

[3] Batang District Court Decision Number 247/Pid.Sus/2019/PN

[4] Directory of Central Java High Court Decisions

Interview:

[1] Personal interview with Guntoro Eka Sekti, Chairman of the Batang District Court, Batang, Thursday 25 November 2021 